Southern Illinois University Carbondale

OpenSIUC

Publications

Department of Zoology

$8-2001$

\title{
Modeling Underwater Visual and Filter Feeding by Planktivorous Shearwaters in Unusual Sea Conditions
}

James R. Lovvorn

Southern Illinois University Carbondale

Cheryl L. Baduini

University of California, Irvine

George L. Hunt Jr.

University of California, Irvine

Follow this and additional works at: http://opensiuc.lib.siu.edu/zool_pubs

(C) 2001 by the Ecological Society of America

Published in Ecology, Vol. 82, No. 8 (August 2001) at doi: 10.1890/

0012-9658(2001)082[2342:MUVAFF]2.0.CO;2

\section{Recommended Citation}

Lovvorn, James R., Baduini, Cheryl L. and Hunt, George L. Jr. "Modeling Underwater Visual and Filter Feeding by Planktivorous Shearwaters in Unusual Sea Conditions." (Aug 2001).

This Article is brought to you for free and open access by the Department of Zoology at OpenSIUC. It has been accepted for inclusion in Publications by an authorized administrator of OpenSIUC. For more information, please contact opensiuc@lib.siu.edu. 


\title{
MODELING UNDERWATER VISUAL AND FILTER FEEDING BY PLANKTIVOROUS SHEARWATERS IN UNUSUAL SEA CONDITIONS
}

\author{
James R. Lovvorn, ${ }^{1,3}$ Cheryl L. Baduini, ${ }^{2}$ And George L. Hunt, JR. ${ }^{2}$
}

${ }^{1}$ Department of Zoology, University of Wyoming, Laramie, Wyoming 82071 USA

${ }^{2}$ Department of Ecology and Evolutionary Biology, University of California, Irvine, California 92697 USA

\begin{abstract}
Short-tailed Shearwaters (Puffinus tenuirostris) migrate between breeding areas in Australia and wintering areas in the Bering Sea. These extreme movements allow them to feed on swarms of euphausiids (krill) that occur seasonally in different regions, but they occasionally experience die-offs when availability of euphausiids or other prey is inadequate. During a coccolithophore bloom in the Bering Sea in 1997, hundreds of thousands of Short-tailed Shearwaters starved to death. One proposed explanation was that the calcareous shells of phytoplanktonic coccolithophores reduced light transmission, thus impairing visual foraging underwater. This hypothesis assumes that shearwaters feed entirely by vision (bite-feeding), but their unique bill and tongue morphology might allow nonvisual filter-feeding within euphausiid swarms. To investigate these issues, we developed simulation models of Short-tailed Shearwaters bite-feeding and filter-feeding underwater on the euphausiid Thysanoessa raschii. The visual (bite-feeding) model considered profiles of diffuse and beam attenuation of light in the Bering Sea among seasons, sites, and years with varying influence by diatom and coccolithophore blooms. The visual model indicated that over the huge range of densities in euphausiid swarms (tens to tens of thousands per cubic meter), neither light level nor prey density had appreciable effects on intake rate; instead, intake was severely limited by capture time and capture probability after prey were detected. Thus, for shearwaters there are strong advantages of feeding on dense swarms near the surface, where dive costs are low relative to fixed intake rate, and intake might be increased by filter-feeding. With minimal effects of light conditions, starvation of shearwaters during the coccolithophore bloom probably did not result from reduced visibility underwater after prey patches were found. Alternatively, turbidity from coccolithophores might have hindered detection of euphausiid swarms from the air.
\end{abstract}

Key words: coccolithophore blooms; diving birds; euphausiids; filter-feeding; foraging models; krill; light attenuation; planktivores; Puffinus tenuirostris; Short-tailed Shearwater; underwater vision; visual foraging.

\section{INTRODUCTION}

Short-tailed Shearwaters (Puffinus tenuirostris) make extreme seasonal movements to deal with spatial and temporal variation in foraging conditions. This species breeds in southeast Australia and migrates to the Bering Sea for the austral winter (Marshall and Serventy 1956). Also, because of insufficient food near breeding colonies, these birds make long trips just before and after breeding, and every 10-19 d during chick-rearing, to feed in more productive Antarctic frontal waters $1000 \mathrm{~km}$ to the south (Nicholls et al. 1998, Weimerskirch and Cherel 1998). These long travels allow the birds to feed on swarms of euphausiids (krill) that occur seasonally in different regions. However, despite migration shifts in response to long-term oceanic changes (cf. Spear and Ainley 1999), die-offs of these shearwaters occasionally occur when euphausiids or other prey fail to achieve local abundance (Oka and Maruyama 1986, Baduini et al. 2001).

Manuscript received 25 May 2000; revised 8 August 2000; accepted 29 August 2000.

${ }^{3}$ E-mail: lovvorn@uwyo.edu
During a coccolithophore bloom in the Bering Sea in 1997, hundreds of thousands of Short-tailed Shearwaters died, apparently from starvation (Sukhanova and Flint 1998, Baduini et al. 2001). One explanation was that the calcareous shells (coccoliths) of phytoplanktonic coccolithophores decreased light transmission, thus impairing visual foraging underwater (Vance et al. 1998). This hypothesis assumes that shearwaters feed entirely by vision (bite-feeding), but their unique tongue and bill morphology might allow nonvisual filter-feeding within euphausiid swarms (Morgan and Ritz 1982).

We investigated the possibility that the coccolithophore bloom impaired visual foraging underwater and thus led to the die-off of shearwaters. To do this, we developed simulation models of Short-tailed Shearwaters bite-feeding and filter-feeding on euphausiids. The visual (bite-feeding) model considered profiles of diffuse and beam attenuation of light in the Bering Sea among seasons, sites, and years with varying influence by diatom and coccolithophore blooms (see Balch et al. 1991, 1996, Garcia-Soto et al. 1995). We also explored the potential importance of filter-feeding to the ability of shearwaters to balance their energy budgets. 


\section{Methods of underwater foraging}

In the eastern Bering Sea, Short-tailed Shearwaters often eat exclusively the euphausiid Thysanoessa raschii when these krill are concentrated either in surface swarms or by bathymetric features that block their diel movement to deeper water (Hunt et al. 1996, Baduini et al. 2001). The shearwaters locate prey by flying within a few meters of the water surface, and then dive directly from the air or after alighting to pursue prey as deep as at least $40 \mathrm{~m}$ (Ogi et al. 1980, Hunt et al. 1996). Shearwaters might exploit bioluminescent prey at greater depths: dives up to $67 \mathrm{~m}$ have been measured in the very similar Sooty Shearwater, Puffinus griseus (Weimerskirch and Sagar 1996). However, Short-tailed Shearwaters in the Bering Sea appear to forage mainly within the photic zone, so their underwater vision during the day probably depends on incident sunlight. While dense coccolithophores might impair detection of euphausiid swarms from the air (see Eriksson 1985, Haney and Stone 1988), they probably also increase beam scattering, decrease light penetration, and thereby reduce visibility of prey underwater.

Effects of light and turbidity on capture rates have been thoroughly investigated for predatory fish both empirically and theoretically (Dunbrack and Dill 1984, Aksnes and Giske 1993, Benfield and Minello 1996, Aksnes and Utne 1997, and references therein), but such effects have seldom been analyzed for birds (Eriksson 1985, Haney and Stone 1988, Wilson et al. 1993, Cannell and Cullen 1998, Wanless et al. 1999). In particular, effects of light on foraging success might differ between planktivorous and piscivorous birds. Many planktivorous fish switch from biting at individual organisms to filter-feeding when the density of zooplankton exceeds certain thresholds, which depend on both light conditions and prey size (O'Connell and Zweifel 1972, Holanov and Tash 1978, James and Findlay 1989, Batty et al. 1990, Gibson and Ezzi 1990). Filter-feeding can continue in near or total darkness (Holanov and Tash 1978, Batty et al. 1990). Planktivorous diving birds such as some shearwaters and prions may exhibit similar transitions in foraging mode (Prince 1980, Morgan and Ritz 1982), and thus respond differently to light conditions than do birds pursuing larger, more dispersed, more evasive prey (e.g., murres, puffins, cormorants).

Morgan and Ritz (1982) proposed that Short-tailed Shearwaters are capable of filter-feeding. They described papillae on the palate and tongue that overlap to form a filtering mesh, and lateral openings at the rear of the bill that allow water to exit the buccal cavity. The mechanism proposed, and supported by some experiments, is that shearwaters alternately open and close their bills while swimming through euphausiid concentrations. When the bill is closed, water and krill collected in the buccal cavity are pushed forward, and the krill are retained by backwardly recurved, overlap-

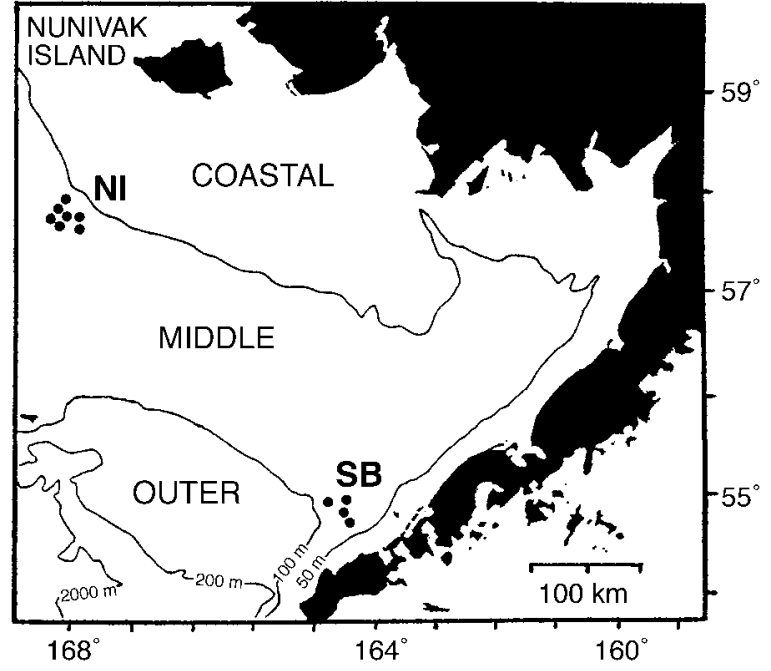

FIG. 1. Sampling stations (solid circles) for light analyses at Slime Bank (SB) and Nunivak Island (NI) study sites in the southeast Bering Sea. Coastal, Middle, and Outer hydrographic domains of the Bering Sea shelf are separated by the 50- and 100-m isobaths, which coincide roughly with the Inner and Middle fronts between these domains (see Kinder and Schumacher 1981).

ping papillae on the palate and tongue. Water passing through this papillary mesh is expelled through lateral gaps near the rear of the bill, thereby reducing the "bow wave" in front of the bill that would otherwise deflect water and krill from entering the mouth (Morgan and Ritz 1982). There have been no underwater observations of shearwaters to confirm their use of this mechanism. Nevertheless, because euphausiid densities are often high enough for filter-feeding, and because filterfeeding would circumvent light limitations on food intake, it is an important option to consider in evaluating effects of coccolithophores on underwater foraging.

\section{Methods \\ Profiles of PAR and beam attenuation}

We measured depth profiles of photosynthetically active radiation (PAR) and beam attenuation coefficient $\left(c_{z}\right)$ along ship transects in the southeast Bering Sea from 26 May to 13 June and 26-29 August in 1997 and 1998. Scalar (i.e., from all directions) PAR was measured with a log quantum irradiance sensor (QSP200L, Biospherical Instruments, San Diego, California). Beam attenuation at $660 \mathrm{~nm}$ was measured with a 25-cm transmissometer (Sea Tech, Corvallis, Oregon).

Light measurements were made at stations along transects roughly perpendicular to shore at two sites in the Bering Sea, Alaska, USA: Slime Bank and Nunivak Island (Fig. 1). As part of another study (see Stockwell et al. 2001), these transects were intended to cross the "Inner" front between Coastal and Middle domains of the southeast Bering Sea shelf; this front between well- 
mixed coastal and stratified offshore waters occurs at about the 50-m isobath (Kinder and Schumacher 1981). To standardize light angle and to avoid tidally induced turbidity nearer shore, we restricted our analyses to casts made between 1100 and 1345 Alaska Daylight Time at outer (deeper) stations. The number of stations meeting these criteria were 3 in June 1997 and 1 (2 casts averaged) in June 1998 at Slime Bank; and 1 in August 1997, 3 ( 1 of these with 2 casts averaged) in June 1998, and 3 in August 1998 at Nunivak Island. Bottom depths at these stations ranged from 90 to 99 $\mathrm{m}$ at Slime Bank and from 53 to $61 \mathrm{~m}$ at Nunivak. Our transmissometer was not working at Slime Bank in August 1997, or at Nunivak in June or August 1997.

Among stations, there were variations in cloud cover and resulting incident radiation, and in wave conditions, which can alter the underwater light field (Stramska and Dickey 1998). To minimize these effects for averaging and comparing profiles among stations, sites, and seasons, we back-calculated incident PAR just below the sea surface from near-surface measurements. Depending on variable depths of the first few measurements in casts, we computed the light attenuation coefficient $k$ for scalar PAR measured at 4 to $4.7 \mathrm{~m}$ vs. the shallowest depth sampled (1.7 to $3.7 \mathrm{~m})$. By Beer's Law, $k=-\ln \left(R_{z} / R_{0}\right) / \Delta z$, where $R_{z}$ is PAR at the deeper depth, $R_{0}$ is PAR at the shallower depth, and $\Delta z$ the distance between these depths. PAR just below the water surface $\left(R_{\mathrm{s}}\right)$ was estimated by substituting this value of $k$ in the same equation rearranged to $R_{\mathrm{s}}=R_{z} / e^{-k z}$, where $z$ is depth of the shallowest measurement. PAR (diffuse visible light) measured at each 1-m depth increment throughout the water column was expressed as a percentage of this back-calculated surface value for that cast. Beam attenuation coefficient $c_{\mathrm{z}}$ was calculated at $1-\mathrm{m}$ depth increments by the equation $c_{z}=$ $-\ln T_{d} / d$, where $T_{\mathrm{d}}$ is beam transmission over the path length $d$ in the transmissometer $(25 \mathrm{~cm})$. Values of $c_{z}$ and percentage of surface PAR at each depth were averaged among casts at the same station if more than one cast was made there, and among stations within the same site (Slime Bank vs. Nunivak) and season (May-June vs. August).

\section{Model of visual foraging}

Visual range is a complex function of the characteristics of prey (size, contrast with background, mobility), predator (retinal sensitivity, eye size), and optical environment (intensity, angle, absorption, and scattering of light) (Lythgoe 1979). Visual ability to detect prey is often considered limited by two different criteria: visual acuity and contrast sensitivity (Snyder et al. 1977, Lythgoe 1979, Breck 1993). Visual acuity is determined by the minimum detectable size of an image on the retina, often measured as the angle subtended by the image. Visual acuity increases with eye size owing to larger images on larger retinas (Snyder et al. 1977, Lythgoe 1979), although this relation may vary with densities of receptors (rods and cones) over all or parts of the retina (Fite and Rosenfield-Wessels 1975, Hayes and Brooke 1990). Contrast is the difference in brightness between an object and its background over some range of visible wavelengths. Water rapidly attenuates light into a narrow band of bluegreen wavelengths, and both fish and birds that pursue prey underwater generally have a predominance of retinal receptors for detecting contrast in that range (Muntz 1972, Lythgoe 1979, Bowmaker and Martin 1985). For birds, visual acuity in air has been the main criterion for assessing visual ability (e.g., Fox et al. 1976, Martin 1982), although contrast sensitivity has been studied in a few cases (Reymond and Wolfe 1981, Hirsch 1982). For visual acuity, the refractive power of the lens in a variety of avian divers can accommodate the loss of corneal refractive power that results from differing refractive indices of air and water (Sivak et al. 1987).

The relative importance of visual acuity and contrast sensitivity varies with light intensity, turbidity, and viewing angle relative to downwelling light; and with prey size relative to predator size and resulting size of the predator's retina (Lythgoe 1979). Breck (1993) argued that zooplanktivores tend to be limited by visual acuity, whereas piscivores are more limited by contrast sensitivity. However, Thetmeyer and Kils (1995) showed that the visibility of mostly translucent prey such as mysids is strongly affected by brightness contrast, and the angles of attack of herring on both mysids and copepods corresponded to optimal contrast.

We based our model of visual foraging (bite-feeding) on that developed by Aksnes and Giske (1993), which recognizes that visual acuity and contrast sensitivity interact to determine thresholds of prey detection (Snyder et al. 1977). In their approach, the threshold for detecting prey depends on a minimum change in the number of photons striking the retina with and without a prey image. Prey with either low or high inherent contrast are more likely to alter the stimulus for a threshold number of receptors if they project a larger image on the retina. The model assumes that prey are detected if the product of apparent contrast at the retina, retinal background irradiance, and area of the prey image on the retina exceeds a threshold. By that model, the maximum vision-based intake rate $(I$, number of prey per second) is given by

$$
I=\frac{C_{\mathrm{ph}}^{-1} N}{\left[C_{\mathrm{ph}} \pi(r \sin \theta)^{2} U\right]^{-1}+N}
$$

(Aksnes and Giske 1993: Eq. 5), where $C_{\mathrm{ph}}$ is capture time (for pursuit and handling after detection) per prey item (seconds), $N$ is prey density (number of prey per cubic meter), $r$ is visual range (meters), $\theta$ is the visual field angle (Fig. 2), and $U$ is swimming speed of the bird (meters per second) (variables are defined in Table $1)$. 
FIG. 2. Visual search volume for diving birds, which depends on visual range $r$, visual field angle $\theta$, and bird swimming speed.

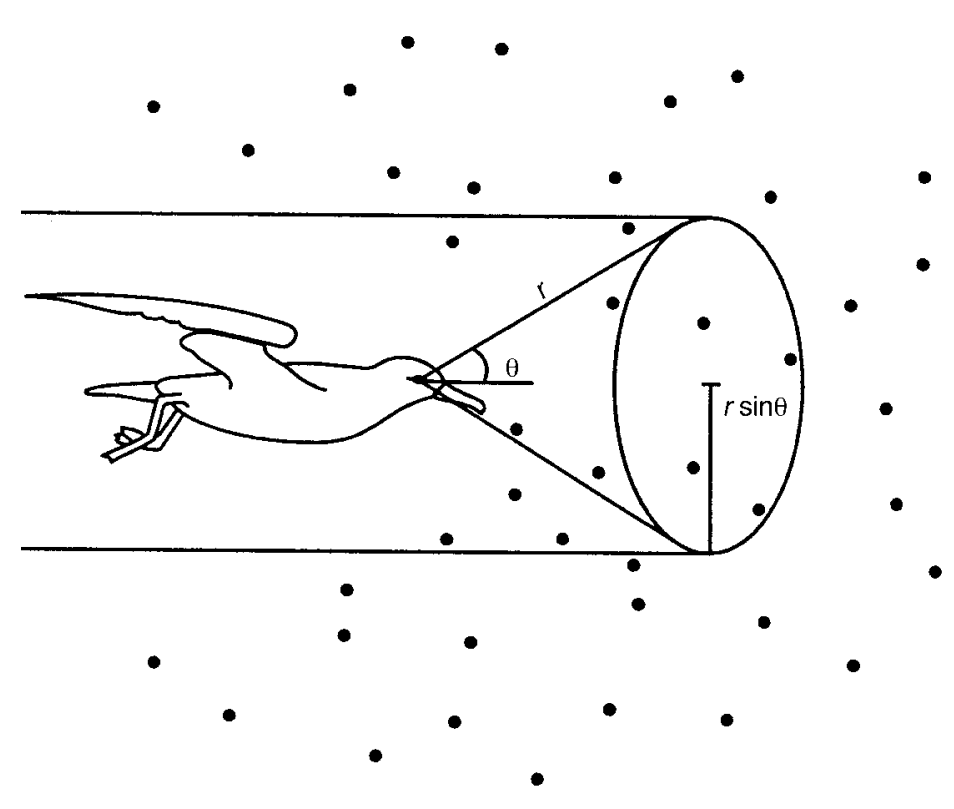

Eq. 1 corresponds to a Michaelis-Menten or Holling type II functional response of the form $I=C_{\mathrm{ph}} N /(s+$ $N)$, in which $C_{\mathrm{ph}}$ is the capture time or maximum value of intake rate $I$ regardless of prey density, and $s$ is the search time coefficient or half-saturation constant equal to the prey density at $0.5 C_{\mathrm{ph}}$ (Aksnes and Giske 1993, Lovvorn and Gillingham 1996). Eq. 1 does not account for increased detectability of moving vs. stationary prey (Wright and O'Brien 1982); thus, we multiply $I$ by a motion detectability factor $M$. Eq. 1 also does not consider the fraction of prey that successfully evades capture when attacked $(1-$ capture probability $G$ for detected prey) (Wright and O'Brien 1984, O'Brien 1987, Link 1996). Including these effects yields an expression for bite-feeding intake rate $I_{\mathrm{b}}$ (number of prey per second) of

$$
I_{\mathrm{b}}=\frac{M G\left(C_{\mathrm{ph}}^{-1} N\right)}{\left[C_{\mathrm{ph}} \pi(r \sin \theta)^{2} U\right]^{-1}+N} .
$$

Visual range $r$ is given by Eq. $16 a$ in Aksnes and Giske (1993):

$$
r^{2} \exp \left(c_{z} r+K z\right)=R_{\mathrm{s}}\left|C_{\mathrm{i}}\right| A_{\mathrm{p}} \Delta S_{\mathrm{e}}^{-1}
$$

where $c_{z}$ is the beam attenuation coefficient (per meter) at depth $z$ below the water surface, $K$ is the coefficient of attenuation (per meter) of diffuse visible irradiance (PAR) over the entire water column, $R_{\mathrm{s}}$ is diffuse scalar irradiance that has just penetrated the water surface $\left(\mu \mathrm{mol} \cdot \mathrm{m}^{-2} \cdot \mathrm{s}^{-1}\right.$; expressed as moles of photons), $C_{\mathrm{i}}$ is inherent contrast of the object, $A_{\mathrm{p}}$ is the plan area of the object tangent to the line of sight (square meters), and $\Delta S_{\mathrm{e}}$ is the threshold change in the rate of photons striking the retina that is detectable by the eye $\left(\mu \mathrm{mol} \cdot \mathrm{m}^{-2} \cdot \mathrm{s}^{-1}\right)$.
Eq. 3 can be rearranged to

$$
r^{2}=R_{\mathrm{s}} e^{-K z} \exp \left(-c_{z} r\right)\left|C_{\mathrm{i}}\right| A_{\mathrm{p}} \Delta S_{\mathrm{e}}^{-1} .
$$

If scalar PAR $\left(R_{z}\right)$ at the depth of interest $z$ is known, Eq. 4 simplifies to

$$
r^{2}=R_{z} \exp \left(-c_{z} r\right)\left|C_{\mathrm{i}}\right| A_{\mathrm{p}} \Delta S_{\mathrm{e}}^{-1} .
$$

The above model was developed for low irradiance levels where the neural response to retinal stimulation is directly proportional to the intensity of incoming light. However, as irradiance increases above a threshold level, the neural response reaches an asymptote (saturation) and changes little with further increase in irradiance (Cornsweet 1970). Consequently, Aksnes and Utne (1997) modified the earlier model to include the term $R_{\max } /\left(k_{\mathrm{s}}+R_{z}\right)$, where $R_{\max }$ is the maximum retinal irradiance that can be processed, and $k_{\mathrm{s}}$ is a saturation parameter for adaptation of the neural response to increasing light levels. Thus, Eq. 5 becomes

$$
r^{2}=\left[R_{\max } /\left(k_{\mathrm{s}}+R_{z}\right)\right] R_{z} \exp \left(-c_{z} r\right)\left|C_{\mathrm{i}}\right| A_{\mathrm{p}} \Delta S_{\mathrm{e}}^{-1} .
$$

The expression $\left(R_{\max } R_{z}\right) /\left(k_{\mathrm{s}}+R_{z}\right)$ is a Michaelis-Menten equation where $R_{\max }$ is the asymptotic value of light processed by the retina above saturation, and $k_{\mathrm{s}}$ is the half-saturation coefficient or the irradiance at which retinal processing is at half its maximum value.

By comparing predictions of this model with data for various fish species, Aksnes and Utne (1997) concluded that the empirically determined parameters $R_{\max }$ and $k_{\mathrm{s}}$ yielded realistic predictions over a wide range of light intensities. However, values of $R_{\max }$ in particular will vary with eye size of the predator. The lens diameter of Short-tailed Shearwaters $(\sim 6.66 \mathrm{~mm}$, see 
TABLE 1. Parameters for the foraging models, and ranges used in uncertainty analyses of selected variables.

\begin{tabular}{|c|c|c|c|}
\hline Symbol & Definition & Value & Range \\
\hline$A_{\mathrm{p}}$ & Plan area of prey tangent to line of vision $\left(\mathrm{m}^{2}\right)$ & $6.7 \times 10^{-5}$ & $3-10 \times 10^{-5}$ \\
\hline$A_{\mathrm{g}}^{\mathrm{p}}$ & Mouth gape area $\left(\mathrm{m}^{2}\right)$ & $2.8 \times 10^{-4}$ & $1.7-2.9 \times 10^{-4}$ \\
\hline$B^{8}$ & Buccal flow fraction of forward swimming speed & 0.8 & $0.6-1.0$ \\
\hline$c_{\mathrm{z}}$ & Beam attenuation coefficient at depth $z\left(\mathrm{~m}^{-1}\right)$ & & $0.724-3.220$ \\
\hline$C_{\mathrm{i}}$ & Inherent contrast of prey & 0.42 & $0.35-0.55$ \\
\hline$C_{\mathrm{ph}}$ & Capture time (pursuit and handling after detection) per prey item (s) & 2 & $1-4$ \\
\hline$E_{\mathrm{f}}^{\mathrm{pn}}$ & Filtration efficiency & 0.8 & $0.6-1.0$ \\
\hline$F_{\mathrm{c}}$ & Fraction of total plan area $\left(A_{\mathrm{p}}\right)$ that is visible core area & 0.6 & $0.4-0.9$ \\
\hline$F_{\mathrm{s}}$ & Fraction of feeding time spent swallowing vs. filtering & 0.1 & $0.05-0.20$ \\
\hline$G$ & Capture probability of prey that are attacked & 0.5 & $0.3-0.7$ \\
\hline$I_{\mathrm{b}}$ & Intake rate by bite-feeding (number of prey/s) & & \\
\hline$I_{\mathrm{f}}$ & Intake rate by filter-feeding (number of prey/s) & & \\
\hline$K_{\mathrm{a}}$ & Vertical attenuation coefficient for diffuse irradiance (PAR) $\left(\mathrm{m}^{-1}\right)$ & & \\
\hline$k_{\mathrm{s}}$ & Saturation parameter for response of retina to light $\left(\mu \mathrm{mol} \cdot \mathrm{m}^{-2} \cdot \mathrm{s}^{-1}\right)$ & 5 & $4-6$ \\
\hline$M$ & Motion detectability factor & 1 & \\
\hline$N$ & Prey density (number of prey $/ \mathrm{m}^{3}$ ) & & \\
\hline$r$ & Visual range (maximum distance a prey type can be recognized) (m) & & \\
\hline$r \sin \theta$ & Radius of cylindrical volume searched by swimming bird (m) & & \\
\hline$R_{\mathrm{s}}$ & Scalar PAR just below the water surface $\left(\mu \mathrm{mol} \cdot \mathrm{m}^{-2} \cdot \mathrm{s}^{-1}\right)$ & & \\
\hline$R_{\mathrm{z}}$ & Scalar PAR at depth $z$ below the water surface $\left(\mu \mathrm{mol} \cdot \mathrm{m}^{-2} \cdot \mathrm{s}^{-1}\right)$ & & $1-1455$ \\
\hline$R_{\max }$ & Maximum retinal irradiance that can be processed $\left(\mu \mathrm{mol} \cdot \mathrm{m}^{-2} \cdot \mathrm{s}^{-1}\right)$ & 8.81 & $7-11$ \\
\hline$\Delta S_{\mathrm{e}}$ & $\begin{array}{l}\text { Eye sensitivity threshold for detecting change in rate } \\
\text { of photons striking the retina }\left(\mu \mathrm{mol} \cdot \mathrm{m}^{-2} \cdot \mathrm{s}^{-1}\right)\end{array}$ & $1.71 \times 10^{-4}$ & $0.5-3.5 \times 10^{-4}$ \\
\hline$U$ & Swimming speed of bird $(\mathrm{m} / \mathrm{s})$ & 1.0 & $0.8-2.6$ \\
\hline$z$ & Depth below water surface $(\mathrm{m})$ & & \\
\hline$\theta$ & Visual field angle (degrees) & $30^{\circ}$ & $20^{\circ}-60^{\circ}$ \\
\hline
\end{tabular}

next section) is $\sim 3.54$ times that of the fish (Gobiusculus flavescens 40-45 mm long) studied by Aksnes and Utne (1997) $(\sim 1.88 \mathrm{~mm}$, cf. Hester 1968, Utne 1997). Assuming that light-processing capacity of the retina is proportional to its area, and that retinal area varies as the square of lens diameter, we increased Aksnes and Utne's (1997) coefficient $T_{1}$ for calculating $R_{\max }$ by $3.54^{2}=12.5$ times. For our values of $\Delta S_{\mathrm{e}}, A_{\mathrm{p}}$, and $C_{\mathrm{i}}$ in Table 1 , and their value for $T_{1}$ of 0.116 , we calculate $R_{\max }=T_{1} \Delta S_{\mathrm{e}} / A_{\mathrm{p}}\left|C_{\mathrm{i}}\right|=8.81 \mu \mathrm{mol} \cdot \mathrm{m}^{-2} \cdot \mathrm{s}^{-1}$. This value agrees well with the irradiance level above which there was no increase in the frequency of pursuing fish by Little Penguins (Eudyptula minor) in controlled experiments (Cannell and Cullen 1998). Visual range is usually measured as the maximum distance at which predators respond to prey, so lack of change in the reaction of Little Penguins to prey above this light level supports our assumption that effective visual range is relatively constant above this irradiance. For the parameter $k_{\mathrm{s}}$, which accounts for neural adaptation of retinal receptors to incident light, we used Aksnes and Utne's (1997) value of $5 \mu \mathrm{mol} \cdot \mathrm{m}^{-2} \cdot \mathrm{s}^{-1}$.

Eq. 6 is solved iteratively for the value of $r$ that corresponds to measured values of PAR and $c_{z}$ at each depth $z$. One can then substitute $r$ into Eq. 2 to calculate intake rate for a given prey density and light conditions, or prey density needed under given light conditions to allow a certain intake rate.

We applied this visual model to Short-tailed Shearwaters feeding on the euphausiid Thysanoessa raschii. We prefer "bite-feeding" to the term "particle-feeding" used by many authors, because the food of filterfeeders is also particulate. For some parameters, there were no data available for birds but only for fish predators. In such cases, we have explored the consequences of error in those parameters with uncertainty analyses to identify variables in most critical need of study for birds.

Prey visibility and density, handling time, and search
volume

For the area of prey tangent to the line of vision $\left(A_{\mathrm{p}}\right.$, Table 1), measurements for $T$. raschii yielded a value of $\sim 6.7 \times 10^{-5} \mathrm{~m}^{2}$. The opaque "core area" of mostly translucent prey that is actually visible to the predator is usually smaller than the total area (Kettle and O’Brien 1978, Thetmeyer and Kils 1995). We assumed the core area fraction $F_{\mathrm{c}}$ of the plan area of $T$. raschii to be 0.6 , and used a range from 0.4 to 0.9 in uncertainty analyses (Table 1).

Inherent contrast is defined as $C_{\mathrm{i}}=\left(R_{\mathrm{obj}}-R_{\mathrm{b}}\right) / R_{\mathrm{b}}$, where $R_{\mathrm{obj}}$ is object radiance and $R_{\mathrm{b}}$ is background radiance (Hester 1968, Anthony 1981). For inherent contrast of prey $C_{\mathrm{i}}$, we used a value of 0.42 measured for mysids at an angle of $60^{\circ}$ above horizontal (Thetmeyer and Kils 1995). (Giske and Aksnes (1992) used a value of 0.5 for copepods.) The value of 0.42 assumes that shearwaters attack euphausiids from below at the angle that maximizes the krills' inherent contrast (Thetmeyer and Kils 1995); thus, the search path depicted in Fig. 2 would be angled upward. In Eqs. 3 to $6, \Delta S_{\mathrm{e}}$ is the sensitivity threshold of the retina for detecting changes in irradiance with and without an image of prey. Lacking direct measurements of $\Delta S_{\mathrm{e}}$, for initial modeling we assumed close correspondence to contrast threshold in fish. According to Hester (1968: Fig. 4), contrast 
threshold of goldfish (Carassius auratus) was related to lens diameter $d_{\mathrm{L}}$ (in millimeters) as antilog $(-0.60$ $\left.d_{\mathrm{L}}+0.230\right)$. Equatorial lens diameter of Manx Shearwaters (Puffinus puffinus) was measured as $5.842 \mathrm{~mm}$ (Martin and Brooke 1991: Table 1). Short-tailed Shearwaters are $\sim 14 \%$ larger than Manx Shearwaters, yielding a lens diameter of $\sim 6.660 \mathrm{~mm}$. This value of $d_{\mathrm{L}}$ gives an estimate of $\Delta S_{\mathrm{e}}$ for Short-tailed Shearwaters of $1.71 \times 10^{-4} \mu \mathrm{mol} \cdot \mathrm{m}^{-2} \cdot \mathrm{s}^{-1}$ (Table 1 ).

The motion detectability factor $M$ is important for some fish predators on zooplankton (Wright and O'Brien 1982, 1984), reflecting an increase in retinal area stimulated by moving prey. We expect that euphausiids are essentially always moving (see Hanamura et al. 1984, O'Brien 1988, Price 1989), but had no data on how movement affects their detectability; thus, we set $M=1$. We assumed the probability $G$ that attacked krill are successfully captured to be 0.5 (see Drenner et al. 1978, Link 1996) (Table 1).

Euphausiids, including Thysanoessa raschii, often occur in swarms a few meters to tens of meters wide. Dip-net, visual, and photographic estimates of density range from thousands to hundreds of thousands per cubic meter for swarming euphausiids of various species (Hanamura et al. 1984, Nicol 1986; review in O'Brien 1988). In contrast, acoustic and tow-net surveys of more dispersed layers yield densities integrated over hundreds of meters of less than a few hundred krill per cubic meter, and usually far lower (Sameoto 1983, Nicol 1986, Simard et al. 1986, Watkins and Murray 1998). No data on relative densities in surface swarms vs. deeper layers are available for Thysanoessa spp., so we based our simulations on ranges of density $N$ for other krill species.

For the capture time $C_{\mathrm{ph}}$ (for pursuit and handling after detection) of fish predators biting at individual prey, various authors have measured or assumed values ranging from 1.2 to $2 \mathrm{~s}$ (Werner and Hall 1974, Eggers 1976, Clark and Levy 1988, Giske and Aksnes 1992). When 15 live krill (Nyctiphanes australis) were placed in a 2.6-L aquarium, Australian salmon (Arripis trutta) averaging $5 \mathrm{~cm}$ long pursued individual krill for 4-5 s each until captured (Morgan and Ritz 1983). Lacking data for diving birds, we varied $C_{\mathrm{ph}}$ from 1 to $4 \mathrm{~s}$ (Table $1)$.

During a given time, a bird searches a cylindrical volume of water of radius $r \sin \theta$, as determined by the visual range $r$ (meters), the visual field angle $\theta$, and the speed $U$ of the bird (meters per second) (Fig. 2). We reasoned that shearwaters swimming through a euphausiid concentration would not reverse their course to capture a krill beside or behind them, and effectively search only in front of them (see Morgan and Ritz 1983, Hall et al. 1986). For initial modeling, we assumed a visual field angle of $30^{\circ}$ based on studies of predatory fish (Giske and Aksnes 1992). We varied this parameter in uncertainty analyses from $20^{\circ}$ to $60^{\circ}$ (Table 1 ), the latter value being the nasal hemifield angle reported for Manx Shearwaters (Martin and Brooke 1991). For shearwaters swimming through a euphausiid concentration after diving to that depth, we assumed speed $U$ to be $1 \mathrm{~m} / \mathrm{s}$ (see Brown et al. 1978). In uncertainty analyses, we varied swimming speed from 0.8 to 2.6 $\mathrm{m} / \mathrm{s}$, the latter value being the maximum burst speed reported for Common Murres (Uria aalge) swimming horizontally in tanks (Swennen and Duiven 1991, Lovvorn et al. 1999).

\section{Model of filter-feeding}

Our model of filter-feeding in Short-tailed Shearwaters was motivated by mechanisms proposed by Morgan and Ritz (1982). The filter-feeding intake rate $I_{\mathrm{f}}$ (number of prey per second) is given by

$$
I_{\mathrm{f}}=A_{\mathrm{g}} U B E_{\mathrm{f}} N\left(1-F_{\mathrm{s}}\right),
$$

where $A_{\mathrm{g}}=$ mouth gape area $\left(\mathrm{m}^{2}\right), U=$ swimming speed of the bird $(\mathrm{m} / \mathrm{s}), B=$ fraction of the bird's swimming speed at which water flows through the buccal cavity, $E_{\mathrm{f}}=$ fraction of incoming prey retained by the rakers, $N=$ prey density (number of krill per cubic meter), and $F_{\mathrm{s}}=$ fraction of total feeding time spent swallowing rather than filtering. With calipers, we measured the height and width of the roughly rectangular gape area at the rear of the bill $\left(A_{\mathrm{g}}\right)$ of five Short-tailed Shearwater carcasses. With the bill opened maximally, $A_{\mathrm{g}}($ mean $\pm 1 \mathrm{SD})$ was $2.944 \times 10^{-4} \pm 0.171 \times 10^{-4}$ $\mathrm{m}^{2}$; with the bill about two-thirds open the value was $1.722 \times 10^{-4} \pm 0.217 \times 10^{-4} \mathrm{~m}^{2}$. In the model we used a value of $2.8 \times 10^{-4} \mathrm{~m}^{2}$, and varied $A_{\mathrm{g}}$ in uncertainty analyses from 1.7 to $2.9 \times 10^{-4}$. Various studies of fish have reported that swimming speed $U$ is either higher (James and Findlay 1989, Batty et al. 1990) or lower (Gibson and Ezzi 1985, 1990, Pepin et al. 1988) during bite-feeding than filter-feeding; for shearwaters we assumed no change from the mean speed of $1 \mathrm{~m} / \mathrm{s}$ used for bite-feeding. Lacking data for birds, we assumed the buccal flow fraction $B$ to be $80 \%$ of swimming speed, filtration efficiency $E_{\mathrm{f}}$ to be 0.8 , and swallowing time fraction $F_{\mathrm{s}}$ to be 0.1 (Gerking 1994, Sanderson et al. 1994, Sims 1999) (Table 1).

\section{Prey size, digestibility, and maximum loading}

Mean mass of individual Thysanoessa raschii can vary among years and seasons, depending on age structure of the population, and on differing age and sex ratios among swarms and between layers at different depths (Berkes 1976, Falk-Petersen 1981, O’Brien 1988, Dalpadado and Skjoldal 1996, Watkins and Murray 1998). These differences influence krill sizes consumed by birds (Hill et al. 1996). Dry mass per individual $T$. raschii averaged $7.51-14.88 \mathrm{mg}$ in different months and years in the Bering Sea (Smith 1991), 7.60 and $20.81 \mathrm{mg}$ for two overlapping generations in Norway (Falk-Petersen 1981), and $9.3 \mathrm{mg}$ in the St. Lawrence estuary, Canada (Simard et al. 1986). For initial modeling, we used $9 \mathrm{mg}$. 

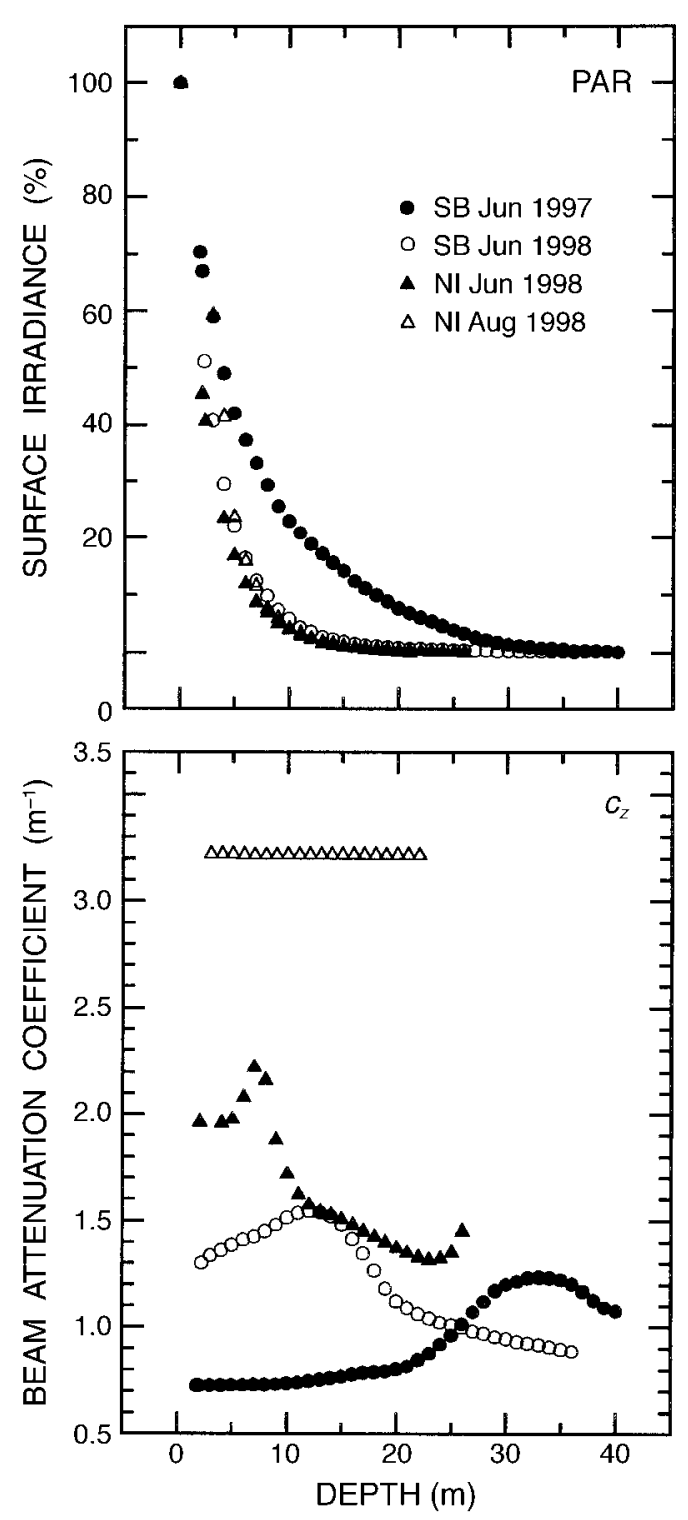

FIG. 3. Percentage of surface irradiance (scalar PAR; top panel) and beam attenuation coefficient $\left(c_{z}, 960 \mathrm{~nm}\right.$; bottom panel) at different depths at Slime Bank (SB) and Nunivak Island (NI), averaged over stations for each site and season. Different curves stop at the shallowest depth of zero PAR among stations for each site and season.

For energy content, Nishiyama (1974) reported 23.0 $\pm 2.2 \mathrm{~kJ} / \mathrm{g}$ dry mass for euphausiids (mainly Thysanoessa spp.) in the Bering Sea. For a 9-mg T. raschii, this value yields $207 \mathrm{~J} /$ individual. We used an assimilation efficiency of 68\% (Jackson 1986, Kirkwood and Robertson 1997). We assumed maximum prey loading to be the highest number of $T$. raschii found in a single esophagus among 98 Short-tailed Shearwaters collected in 1997: 2560 individual krill (C. L. Baduini, unpublished data).

\section{Uncertainty analyses}

We evaluated effects of variation in selected parameters (Table 1) on model estimates of intake rate $I$. Results of uncertainty analyses can depend strongly on the ranges over which parameters are varied. Thus, we did not vary parameters by a constant percentage, because such an arbitrary range might be greater or less than variation observed in nature. All parameters were considered uniformly distributed within ranges considered likely to occur.

In a Latin hypercube design (see Lovvorn and Gillingham 1996), the uniform distributions (Table 1) were divided into 150 equal intervals. For each foraging event, values for each parameter were randomly selected from intervals chosen randomly without replacement. After simulations, the dependent variable (intake rate) was regressed against the independent variables (randomly chosen parameter values) for each feeding event $(n=150)$. Relative partial sums of squares (RPSS) indicated the amount of variance in intake rate explained by variation of individual parameters, with effects of other parameters statistically removed. We also report partial coefficients of determination (partial $r^{2}$ ), because parameters can have high partial $r^{2}$ but account for small residual variances in RPSS.

\section{RESULTS}

\section{Profiles of PAR and beam attenuation}

At sites and seasons for which both PAR and beam transmission were measured, the main difference in PAR profiles was between Slime Bank in June 1997 and other sites and times (Fig. 3). This difference might represent conditions before and after the initial coccolithophore bloom in late summer 1997, which lingered overwinter and through summer 1998. However, Slime Bank was outside the main coccolithophore bloom, so light conditions there in June 1998 might also reflect higher diatom concentrations. Beam attenuation in the upper $25 \mathrm{~m}$ was also lower at Slime Bank in June 1997 than at other sites and seasons (Fig. 3). However, unlike PAR (diffuse visible light), beam attenuation varied substantially among the other sites, being especially high at Nunivak in August 1998. Because the transmissometer malfunctioned, beam attenuation was not measured at Slime Bank or Nunivak in August 1997 when the die-off of shearwaters occurred. Interestingly, although beam attenuation was especially high at Nunivak in August 1998, and PAR transmission was low during that time (Fig. 3), the PAR profile at Nunivak in August 1997 (presumed peak of the coccolithophore bloom) instead resembled the pre-bloom profile at Slime Bank in June 1997 (cf. Figs. 3 and 4). Only one station met our criteria for PAR analysis at Nunivak in August 1997 (see Methods); the bloom was patchy, so this station might not have represented the densest part of the bloom. 


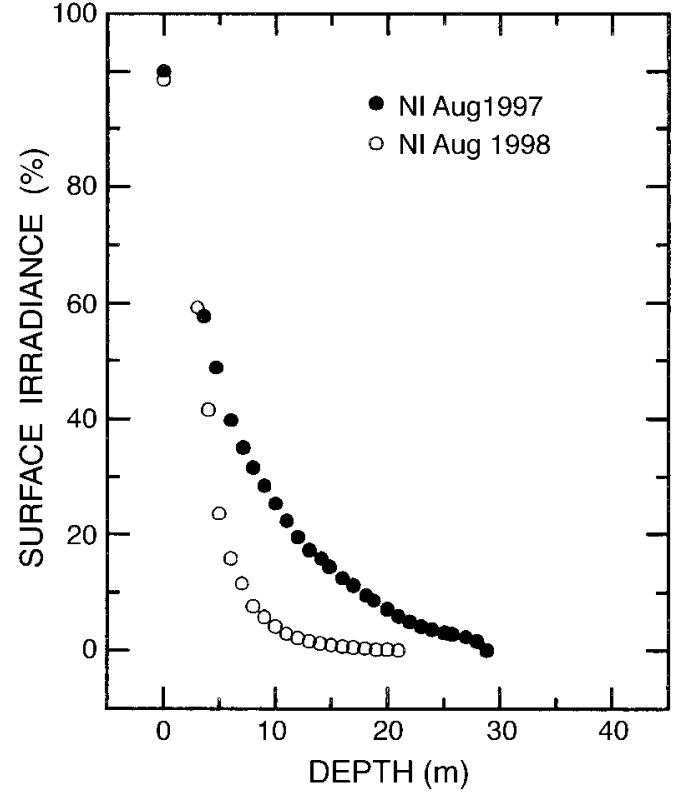

FIG. 4. Depth profiles of the percentage of surface irradiance (scalar PAR) at Nunivak Island (NI) in August 1997 and 1998. These data are not included in Fig. 3 because corresponding beam attenuation coefficients were not measured.

\section{Limiting influences on bite-feeding and filter-feeding}

Depth profiles of the visual range of shearwaters to detect individual euphausiids varied among sites and seasons (Fig. 5). As profiles of PAR were smooth and often the same, varying magnitudes and fluctuations of visual range often corresponded to patterns of beam attenuation (cf. Figs. 3 and 5). As influenced by the saturation function (Eq. 6), visual range changed little from the surface to depths of 15-25 $\mathrm{m}$, depending on light conditions. Below the depth at which retinal processing was saturated, visual range decreased rapidly, especially in the bottom meter of the photic zone.

Capture time (for pursuit and handling after detection) and capture probability (capture rate for prey that are attacked) limited intake rates at all euphausiid densities $>5-10 \mathrm{krill} / \mathrm{m}^{3}$ (Figs. 6 and 7). This limitation by capture time and capture probability meant that variations in light conditions among depths, sites, and seasons had negligible effects on intake rates (Fig. 6). Although incorrect model assumptions might cause inaccuracies, varying other parameters over realistic ranges had no appreciable effects relative to those of capture time and capture probability (Table 2 ). This result is so dramatic as to be generally reliable. Because of severe limitation by capture time and capture probability at all prey densities and light levels, the only way shearwaters can increase intake rate is to circumvent these limits, as by filter-feeding. Our models suggest that intake rates by bite-feeding are greater than by filter-feeding at euphausiid densities lower than 900-2200 krill/ $\mathrm{m}^{3}$, while above that level intake from filter-feeding is greater (Figs. 6 and 7).

The potential importance of filter-feeding to shearwaters eating euphausiids is shown by its dramatic effects on the time they must spend foraging underwater. As measured with doubly labeled water, daily energy expenditure (DEE) of the similar Wedge-tailed Shearwater (Puffinus pacificus) was $614 \mathrm{~kJ} / \mathrm{d}$ (Ellis et al. 1983). If we assume the same value for Short-tailed Shearwaters, they would require on average at least $3 \mathrm{~h}$ 18 min bite-feeding underwater each day to maintain energy balance (Table 3, assuming 9 mg dry mass per euphausiid). If the euphausiids were much larger than often occurs ( $15 \mathrm{mg}$ dry mass, $345 \mathrm{~J}$ ), the average time needed to meet DEE through bite-feeding would still be $>2 \mathrm{~h}$ underwater (handling time would also increase somewhat). Our field observations indicate that single surface swarms of euphausiids (or multiple swarms that occur in a small area) typically disperse after 30-60 min of intensive feeding by shearwaters. During such foraging periods, individual birds spend far less than these times actually underwater, and the duration of swarming events would be much less than the time required to fill their esophagi via bite-feeding (Table 3).

Thus, we expect that even if low-density (nonswarming) euphausiid concentrations $\left(<1550 \mathrm{krill} / \mathrm{m}^{3}\right)$ occurred near the surface where shearwaters could locate them, neither bite-feeding nor filter-feeding would yield adequate intake to meet the birds' energy needs. Because of limitation by capture time and capture probability, bite-feeding shearwaters could not increase their intake rate by finding higher density swarms. In contrast, shearwaters filter-feeding on swarms, with typical densities far greater than $1550 \mathrm{krill} / \mathrm{m}^{3}$, could probably balance their DEE in $3 \mathrm{~h}$ or less underwater (Table 3). At swarm densities $>10000 \mathrm{krill} / \mathrm{m}^{3}$, the birds might fill their

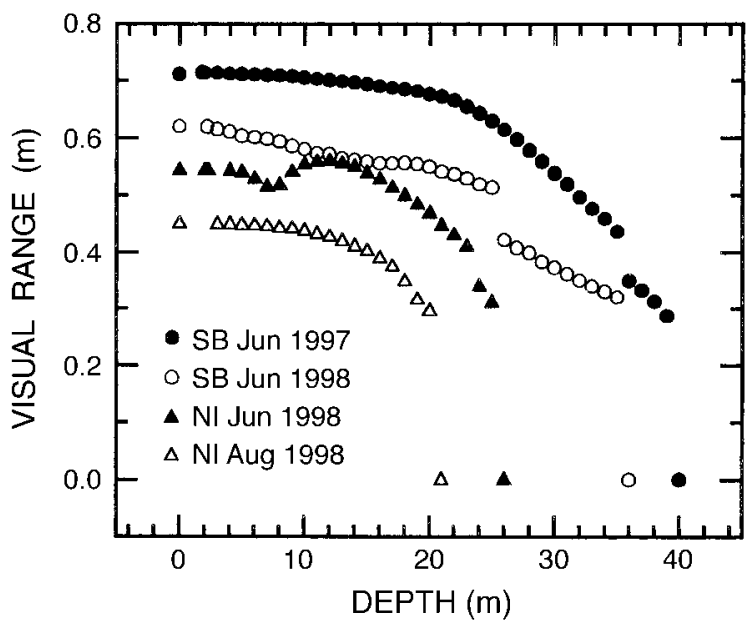

FIG. 5. Modeled visual range for Short-tailed Shearwaters to detect individual euphausiids at different depths at Slime Bank (SB) in June 1997 and 1998, and at Nunivak Island (NI) in June and August 1998, based on light conditions measured at those sites (Fig. 3). 

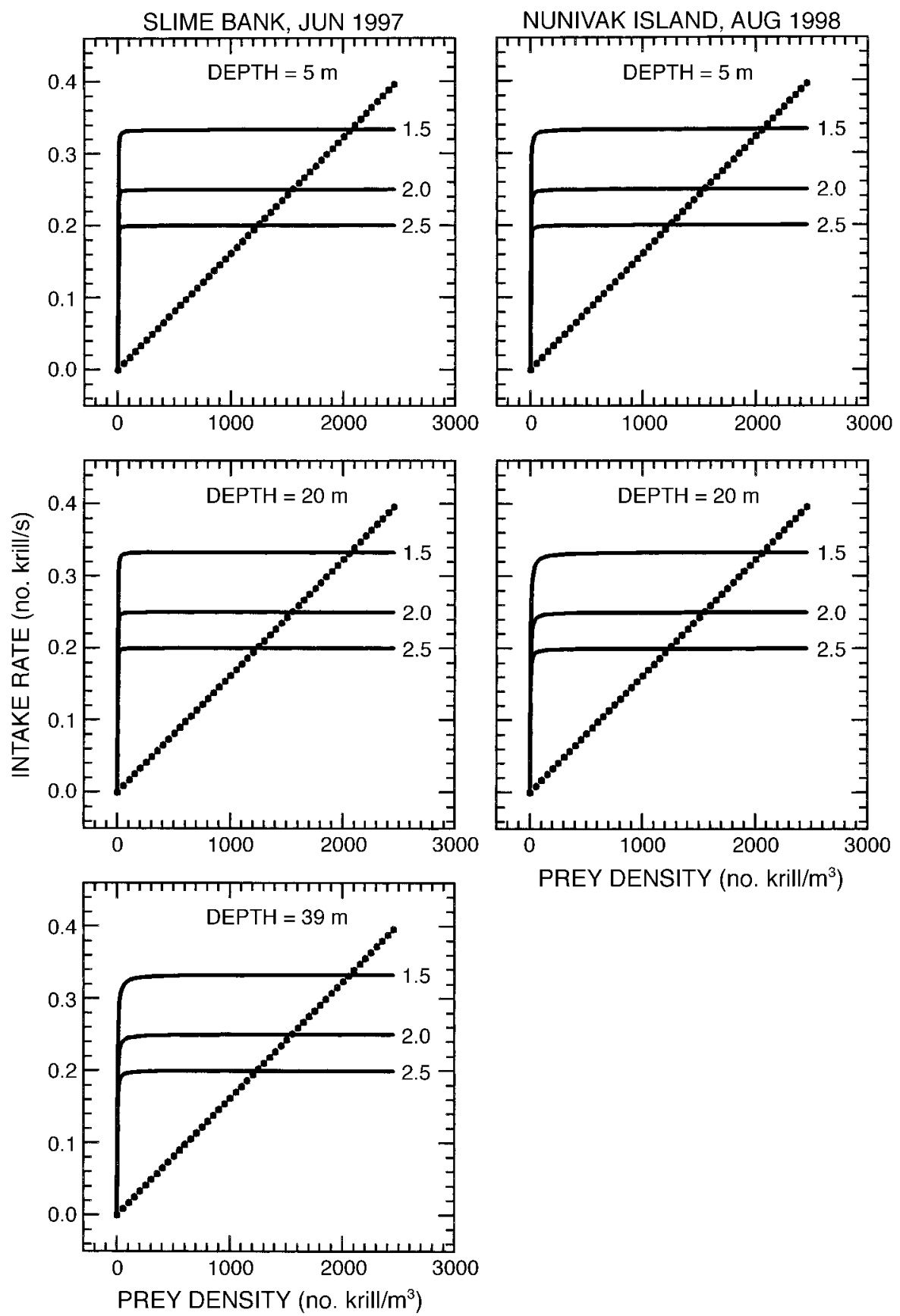

FIG. 6. Modeled intake rates of Short-tailed Shearwaters bite-feeding (lines) and filter-feeding (circles) on the euphausiid Thysanoessa raschii for different light conditions (different sites and times; cf. Figs. 3 and 5), feeding depths, capture times $C_{\mathrm{ph}}(1.5,2.0$, and $2.5 \mathrm{~s})$, and krill densities. Curves for $39 \mathrm{~m}$ at Slime Bank, and $20 \mathrm{~m}$ at Nunivak, are for light conditions $1 \mathrm{~m}$ above zero PAR (Figs. 3 and 5). Capture probability $G=0.5$.

esophagi on a single swarm and need to find only one or two swarms during a day. We have no data on how long it takes shearwaters to locate swarms. However, based on the frequency with which we encountered swarms along ship transects, it appears that it might take the birds at least several hours to find new swarms. Our models suggest that filter-feeding would greatly increase the ability of shearwaters to take advantage of high euphausiid concentrations in surface swarms or in dense layers, and thereby meet their energy needs.

\section{Uncertainty analysis}

In accordance with other analyses (Figs. 6 and 7), variations in capture time and capture probability after 


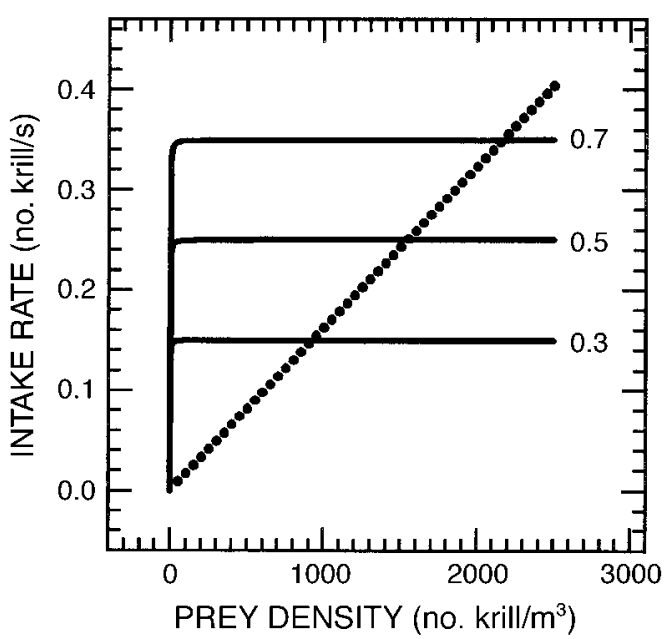

FIG. 7. Modeled intake rates of Short-tailed Shearwaters bite-feeding (lines) and filter-feeding (circles) on the euphausiid Thysanoessa raschii for capture probabilities $G$ of 0.3 , 0.5 , and 0.7. Water depth $=5 \mathrm{~m}$ for light conditions at Slime Bank in June 1997 (Fig. 3), and capture time $C_{\mathrm{ph}}=2 \mathrm{~s}$.

detecting prey accounted for $>98 \%$ of RPSS for intake rate (Table 2). To ensure these results did not depend on ranges of variation used, we did a second set of uncertainty analyses in which capture time $C_{\mathrm{ph}}$ and capture probability $G$ were varied over smaller ranges (1$2 \mathrm{~s}$ vs. $1-4 \mathrm{~s}$, and $0.4-0.6$ vs. $0.3-0.7)$. Comparing five sets of 150 simulations each for broad and narrow ranges, RPSS values $(\%)$ for these variables (mean $\pm 1 \mathrm{SD}$ ) did not differ $\left(68.70 \pm 3.00\right.$ vs. $67.16 \pm 5.97$ for $C_{\mathrm{ph}}$,

TABLE 2. Relative partial sums of squares (RPSS) and partial coefficients of determination (partial $r^{2}$ ) from uncertainty analyses of the visual foraging (bite-feeding) model for Short-tailed Shearwaters eating the euphausiid Thysanoessa raschii.

\begin{tabular}{lcc}
\hline \hline \multicolumn{1}{c}{ Parameter } & RPSS $(\%)$ & Partial $r^{2}$ \\
\hline Capture time, $C_{\mathrm{ph}}$ & 68.70 & 0.601 \\
Capture probability, $G$ & 29.60 & 0.240 \\
Swimming speed of bird, $U$ & 0.27 & 0.002 \\
Beam attenuation coefficient, $c_{\mathrm{z}}$ & 0.26 & 0.002 \\
PAR, $R_{\mathrm{z}}$ & 0.25 & 0.002 \\
Visual field angle, $\theta$ & 0.24 & 0.002 \\
Eye sensitivity threshold, $\Delta S_{\mathrm{e}}$ & 0.22 & 0.001 \\
Core fraction, $F_{\mathrm{c}}$ & 0.13 & $<0.001$ \\
Inherent contrast, $C_{\mathrm{i}}$ & 0.12 & $<0.001$ \\
Plan area of prey, $A_{\mathrm{p}}$ & 0.06 & $<0.001$ \\
\hline
\end{tabular}

Notes: The simulation included 150 runs, each run with parameter values randomly selected from ranges in Table 1 by the Latin hypercube method. RPSS values indicate the relative variance in intake rate (number of krill per second) explained by variation in each parameter, with effects of the other parameters statistically removed. Visual range $r$ is not included because it is calculated from several of the other variables (see Methods: Eq. 6). Prey density was set at 500 $\mathrm{krill} / \mathrm{m}^{3}$, within the range where visual bite-feeding should be more profitable than filter-feeding (cf. Figs. 6 and 7). Partial $r^{2}$ values are sequential values from stepwise multiple regression (multiple $R^{2}=0.854, P<0.001$ ).
TABLE 3. Model estimates of intake rates, and time underwater needed to achieve maximum prey loading (2560 T. raschii $=529.92 \mathrm{~kJ}$ ) and to offset daily energy expenditure $(\mathrm{DEE}=614 \mathrm{~kJ})$, for filter-feeding Short-tailed Shearwaters.

\begin{tabular}{cccc}
\hline \hline $\begin{array}{c}\text { Prey } \\
\text { density } \\
\left(\mathrm{kril1} / \mathrm{m}^{3}\right)\end{array}$ & $\begin{array}{c}\text { Intake } \\
\text { rate }(\mathrm{J} / \mathrm{s})\end{array}$ & $\begin{array}{c}\text { Time } \\
\text { underwater } \\
\text { to fill esophagus } \\
\text { (hours:minutes) }\end{array}$ & $\begin{array}{c}\text { Time } \\
\text { underwater } \\
\text { to meet DEE } \\
\text { (hours:minutes) }\end{array}$ \\
\hline 10 & 0.33 & $446: 04$ & $510: 53$ \\
50 & 1.67 & $88: 09$ & $102: 51$ \\
500 & 16.69 & $8: 49$ & $10: 13$ \\
1550 & 51.75 & $2: 51$ & $3: 18$ \\
3000 & 100.15 & $1: 28$ & $1: 42$ \\
7000 & 233.69 & $0: 38$ & $0: 44$ \\
10000 & 338.85 & $0: 26$ & $0: 31$ \\
15000 & 500.77 & $0: 18$ & $0: 20$ \\
\hline
\end{tabular}

Note: Owing to limitation by capture time and capture probability, time bite-feeding needed to meet DEE (3:18 $=3 \mathrm{~h}$ $18 \mathrm{~min}$ ) is constant at all euphausiid densities and equal to intake via filter-feeding at $1550 \mathrm{krill} / \mathrm{m}^{3}\left(C_{\mathrm{ph}}=2 \mathrm{~s}, G=0.5\right.$; Figs. 6 and 7).

$29.60 \pm 3.16$ vs. $29.39 \pm 5.26$ for $G$ ). For filter-feeding, bird swimming speed and mouth gape area were most influential, explaining $>85 \%$ of RPSS (Table 4 ).

\section{Discussion}

During both breeding and migration, Short-tailed Shearwaters move between widely separated foraging areas. They are thought to feed little while migrating between Australia and the Bering Sea, perhaps explaining occasional mass mortalities toward the end of both northward and southward migrations (Serventy 1967, Oka and Maruyama 1986). These extreme movements and periodic die-offs at different places and times (Oka et al. 1987, Baduini et al. 2001) suggest that these shearwaters depend on particular foraging conditions that sometimes fail to occur. Similar movements are made by Sooty Shearwaters (Puffinus griseus), which appear to track oceanographic variations among the Peru Current, California Current, and northcentral Pacific Ocean (Spear and Ainley 1999). Because or in spite of this foraging strategy, both species are

TABLE 4. Relative partial sums of squares (RPSS) and partial coefficients of determination (partial $r^{2}$ ) from uncertainty analyses of the filter-feeding model for Short-tailed Shearwaters eating the euphausiid Thysanoessa raschii.

\begin{tabular}{lrc}
\hline \hline \multicolumn{1}{c}{ Parameter } & RPSS & Partial \\
& $(\%)$ & $r^{2}$ \\
\hline Swimming speed of bird, $U$ & 50.24 & 0.454 \\
Mouth gape area, $A_{\mathrm{g}}$ & 34.92 & 0.358 \\
Filtration efficiency, $E_{\mathrm{f}}$ & 8.08 & 0.063 \\
Buccal flow fraction of swimming speed, & 6.37 & 0.056 \\
$\quad B$ & & \\
Fraction of feeding time spent swallowing, & 0.39 & 0.003
\end{tabular}
$F_{\mathrm{s}}$

Notes: Procedures were the same as described in Table 2. Partial $r^{2}$ values are sequential values from stepwise multiple regression. Prey density was set at $3000 \mathrm{krill} / \mathrm{m}^{3}$ (cf. Fig. 6). Multiple $R^{2}=0.934, P<0.001$. 
very abundant: with past estimates of at least $3-10 \times$ $10^{6}$ Short-tailed Shearwaters in the eastern Bering Sea, they are the most numerous bird species there from June through September (Hunt et al. 1981).

Thus, shearwaters are not only important top predators in terms of population numbers and biomass consumed (Schneider and Shuntov 1993), but are also sensitive indicators of oceanographic and food web change over large areas of the globe (Oka et al. 1987, Veit et al. 1997, Baduini et al. 2001, Stockwell et al. 2001). Climate shifts and eutrophication can strongly affect the productivity and optical properties of coastal waters (Zaitsev 1992, Sugimoto and Tadokoro 1997), which in turn may affect the relative abundance and impacts of predators with different foraging modes (e.g., bitefeeding vs. filter-feeding) (Nonacs et al. 1994, Eiane et al. 1997, Jansen et al. 1998, Willette et al. 1999). The ability of shearwaters to feed efficiently on euphausiids, perhaps by filter-feeding, may be a key factor in their seasonal dominance of the local seabird fauna and their impacts on this important food web component (Frost and Lowry 1984, Schneider and Shuntov 1993).

\section{Light attenuation and bloom effects on foraging}

Given that beam transmission varied substantially regardless of similar PAR profiles (Fig. 3), it appears that diffuse and beam attenuation can respond differently to bloom or other conditions affecting underwater light. PAR (diffuse light) affects vision mainly by determining the number of photons available to be reflected from an object. Beam attenuation, by altering reflected beams on their path between object and retina, affects clarity of contrast between the object's image and its surroundings (resolution of its silhouette). If the relative patterns of PAR, beam transmission, and visual range in Figs. 3-5 result from the coccolithophore bloom, coccolithophores might have affected underwater vision more by scattering beams than by absorbing diffuse light. During blooms in other areas, density of detached coccoliths was strongly correlated with both beam and diffuse attenuation, but these effects resulted mostly from scattering rather than absorption of light (Balch et al. 1991, Garcia-Soto et al. 1995).

Regardless of optical effects, uncertainty analyses indicated that variation in both beam and diffuse attenuation of light had negligible influence on bite-feeding relative to effects of capture time and capture probability (Table 2, Fig. 6). Thus, any effects of the 1997 coccolithophore bloom on shearwaters probably did not result from decreased visibility underwater.

\section{Feeding modes, energetics, and foraging strategies}

For birds feeding on small prey in dense concentrations that may be hard to find or sporadically accessible (e.g., in surface swarms), there appear to be strong advantages to filter-feeding. In our model, intake rates by bite-feeding were determined almost entirely by capture time and capture probability at all prey densities, and the only way to increase intake rate regardless of prey density is to circumvent these limiting factors. Facing similar constraints, many fish have evolved the ability to bite-feed or filter-feed facultatively depending on prey size, prey density, and light conditions (O'Connell and Zweifel 1972, Holanov and Tash 1978, James and Findlay 1989, Batty et al. 1990, Gibson and Ezzi 1990). Prey densities at which shifts to filter-feeding occur are lower for smaller prey, which are less cost effective to attack individually. Our results suggest that $T$. raschii is small enough relative to shearwaters that bite-feeding is seldom cost effective (cf. Fig. 6, Table 3). Short-tailed Shearwaters feed on fish and squid elsewhere (Baltz and Morejohn 1977, Ogi et al. 1980, Gould et al. 2000), and since 1997 have expanded their diet in the southeastern Bering Sea to include more fish in the spring and predominantly fish in the fall (C. L. Baduini and G. L. Hunt, unpublished data). The much higher energy density of fish and squid probably makes bite-feeding more profitable than is possible with euphausiids (Brown et al. 1981, Chu 1984).

Besides filter-feeding, shearwaters can also improve foraging profitability by finding euphausiids near the water surface, thereby minimizing dive costs relative to intake rate. By this argument, shearwaters should generally ignore even dense euphausiid layers at deeper depths, and search out intermittent surface swarms. Although Short-tailed Shearwaters at times feed on euphausiid concentrations at depths up to $40 \mathrm{~m}$ or more (Hunt et al. 1996), they typically feed on swarms near the surface and apparently cannot feed profitably on more dispersed layers at depth (Brown et al. 1981, Weimerskirch and Cherel 1998). Based on continuous observations from our ship over thousands of kilometers, it appears that shearwaters find swarms by flying individually or in groups of $2-5$ birds, which stay in loose visual range of other such groups spread out over large areas (cf. Haney et al. 1992). When a swarm is located by vision or perhaps olfaction (Nevitt 1999), hundreds to thousands of shearwaters quickly converge on the area, arriving in small groups from multiple directions. Cost of flight for these dynamic soarers is probably less than costs of diving by wing propulsion (cf. Lovvorn and Jones 1994), and this strategy of cooperative aerial search with minimal dive depths is probably more efficient energetically than searching for euphausiid layers at greater depths by diving. However, if euphausiids stay in deeper layers and do not form surface swarms, what is usually a very profitable strategy can be disastrous, as indicated by the high population numbers of shearwaters punctuated by occasional massive die-offs (Oka and Maruyama 1986, Baduini et al. 2001). 


\section{Alternative explanations for shearwater starvation}

If foraging by shearwaters underwater was not impaired by coccolithophore effects on light conditions, then why did they starve during the bloom of August 1997? The overall density of euphausiids (adults + juveniles) in 1997 did not differ significantly from densities during studies in 1980 and 1981 when no shearwater die-offs were reported (Stockwell et al. 2001). However, greater turbidity and backscattering of light might have impaired the ability of shearwaters to locate swarms from the air (cf. Eriksson 1985, Haney and Stone 1988). It would be useful to develop another model of visual searching for prey patches by seabirds in flight, to complement our models of foraging underwater. However, that problem is quite different, involving aspects of how flight speed and altitude affect visual discrimination (Land 1999), and how irradiance, sun angle, and reflection interact with surface waves and viewing angle to affect the visibility of objects at varying depths underwater. To our knowledge there is no integrated theory or existing body of work on these topics from an ecological perspective. Consequently, we have limited our analysis to effects of light conditions on foraging underwater.

\section{Relevance to other diving birds}

Another group of diving birds that are very abundant in northern seas, auklets of the family Alcidae, also feed mainly or entirely on zooplankton (copepods, amphipods, euphausiids, jellyfish) (Hunt et al. 1993, 1998). Auklets generally lack the long overlapping papillae on the palate and tongue, and openings near the rear of the bill for exit of water, that suggest filterfeeding in Short-tailed Shearwaters (cf. Bédard 1969, Morgan and Ritz 1982). Of planktivorous auklets we examined, including Parakeet Auklet (Cyclorhynchus psittacula), Cassin's Auklet (Ptychoramphus aleuticus), Crested Auklet (Aethia cristatella), Whiskered Auklet (A. pygmaea), and Least Auklet (A. pusilla), all had smooth tongues and mostly short palatal papillae; only the Cassin's Auklet showed a tendency for longer, recurved palatal papillae and openings near the rear of the bill. Auklets may depend on bite-feeding in dense prey concentrations, with high capture rates that are nevertheless lower than possible by filter-feeding (Fig. 6). However, as for shearwaters, no detailed observations have been made of underwater feeding by planktivorous auklets.

Our results for planktivorous shearwaters are likely quite different than for piscivorous diving birds that pursue much larger, more evasive prey. Although elements of the bite-feeding model will be similar, the fraction of detected prey that are pursued, the fraction of pursued prey that are caught, and handling times to subdue, manipulate, and swallow prey will differ. For example, rather than values of a few seconds used for capture rate (including pursuit and handling) in our planktivore model ( $C_{\mathrm{ph}}$, Table 1$)$, Common Mergansers (Merganser merganser) required on average $2.7 \mathrm{~s}$ to pursue and capture salmon smolts in enclosed stream sections, and $9.2 \mathrm{~s}$ to subdue and eat the smolts (Wood and Hand 1985). Great Crested Grebes (Podiceps cristatus) spent 2-267 s (mean $29.6 \mathrm{~s}$ ) just manipulating 2-20 cm fish at the surface before swallowing them (Ulenaers et al. 1992). Studies are needed on pursuit and capture rates of piscivorous diving birds in regard to light levels, fish density, and fish size (e.g., Cannell and Cullen 1998).

In summary, our models indicate that mass starvation of Short-tailed Shearwaters during the 1997 coccolithophore bloom in the Bering Sea probably did not result from reduced visibility underwater. A more likely explanation is that greater turbidity affected the birds' ability to locate euphausiid swarms from the air. Intake rates of bite-feeding shearwaters are strongly limited by capture time and capture probability, and effective filter-feeding requires very high prey densities. As a result, there are strong advantages to feeding on surface swarms where dive costs are low relative to fixed intake rate, and where intake might be increased by filterfeeding. Thus, changes in water column structure, prey density and dispersion, and bloom or other effects on light conditions will impact marine top predators differently depending on prey size and foraging mode of the predator (bite-feeding vs. filter-feeding) (Eiane et al. 1997). Investigation of mechanisms via field observations, experimental measurements, and integrative modeling should yield better understanding and prediction of how top predators are affected by oceanographic changes.

\section{ACKNOWLEDGMENTS}

We thank the Captain and crew of the R/V Alpha Helix for their assistance during cruises, Sigrid Salo and Nancy Kachel for coordinating instrument casts, and Steve Zeeman for help with light data. We are especially grateful to Jeff Williams of the Alaska Maritime National Wildlife Refuge for collecting auklets. This research was supported by National Science Foundation grants OPP-9813979 to J. R. Lovvorn and OPP-9617287 to G. L. Hunt.

\section{Literature Cited}

Aksnes, D. L., and J. Giske. 1993. A theoretical model of aquatic visual feeding. Ecological Modelling 67:233-250.

Aksnes, D. L., and A. C. W. Utne. 1997. A revised model of visual range in fish. Sarsia 82:137-147.

Anthony, P. D. 1981. Visual contrast thresholds in the cod Gadus morhua L. Journal of Fish Biology 19:87-103.

Baduini, C. L., K. D. Hyrenbach, K. O. Coyle, A. Pinchuk, V. Mendenhall, and G. L. Hunt. 2001. Mass mortality of Short-tailed Shearwaters in the south-eastern Bering Sea during summer 1997. Fisheries Oceanography 10:117-130.

Balch, W. M., P. M. Holligan, S. G. Ackleson, and K. J. Voss. 1991. Biological and optical properties of mesoscale coccolithophore blooms in the Gulf of Maine. Limnology and Oceanography 36:629-643.

Balch, W. M., K. A. Kilpatrick, and C. C. Trees. 1996. The 1991 coccolithophore bloom in the central North Atlantic. I. Optical properties and factors affecting their distribution. Limnology and Oceanography 41:1669-1683. 
Baltz, D. M., and G. V. Morejohn. 1977. Food habits and niche overlap of seabirds wintering on Monterey Bay, California. Auk 94:526-543.

Batty, R. S., J. H. S. Blaxter, and J. M. Richard. 1990. Light intensity and the feeding behaviour of herring, Clupea harengus. Marine Biology 107:383-388.

Bédard, J. 1969. Adaptive radiation in Alcidae. Ibis 111:189198.

Benfield, M. C., and T. J. Minello. 1996. Relative effects of turbidity and light intensity on reactive distance and feeding of an estuarine fish. Environmental Biology of Fishes 46:211-216.

Berkes, F. 1976. Ecology of euphausiids in the Gulf of St. Lawrence. Journal of the Fisheries Research Board of Canada 33:1894-1905.

Bowmaker, J. K., and G. R. Martin. 1985. Visual pigments and oil droplets in the penguin, Spheniscus humboldti. Journal of Comparative Physiology A156:71-77.

Breck, J. E. 1993. Foraging theory and piscivorous fish: are forage fish just big zooplankton? Transactions of the American Fisheries Society 122:902-911.

Brown, R. G. B., S. P. Barker, D. E. Gaskin, and M. R. Sandeman. 1981. The foods of Great and Sooty Shearwaters Puffinus gravis and $P$. griseus in eastern Canadian waters. Ibis 123:19-30.

Brown, R. G. B., W. R. P. Bourne, and T. R. Wahl. 1978. Diving by shearwaters. Condor 80:123-125.

Cannell, B. L., and J. M. Cullen. 1998. The foraging behaviour of Little Penguins Eudyptula minor at different light levels. Ibis 140:467-471.

Chu, E. W. 1984. Sooty Shearwaters off California: diet and energy gain. Pages 64-71 in D. N. Nettleship, G. A. Sanger, and P. F. Springer, editors. Marine birds: their feeding ecology and commercial fisheries relationships. Canadian Wildlife Service Special Publication, Ottawa, Ontario, Canada.

Clark, C. W., and D. A. Levy. 1988. Diel vertical migrations by juvenile sockeye salmon and the antipredation window. American Naturalist 131:271-290.

Cornsweet, T. N. 1970. Visual perception. Academic Press, London, UK.

Dalpadado, P., and H. R. Skjoldal. 1996. Abundance, maturity and growth of the krill species Thysanoessa inermis and T. longicaudata in the Barents Sea. Marine Ecology Progress Series 144:175-183.

Drenner, R. W., J. R. Strickler, and W. J. O'Brien. 1978. Capture probability: the role of zooplankter escape in the selective feeding of planktivorous fish. Journal of the Fisheries Research Board of Canada 35:1370-1373.

Dunbrack, R. L., and L. M. Dill. 1984. Three-dimensional prey reaction field of the juvenile coho salmon (Oncorhynchus kisutch). Canadian Journal of Fisheries and Aquatic Sciences 41:1176-1182.

Eggers, D. M. 1976. Theoretical effect of schooling by planktivorous fish predators on rate of prey consumption. Journal of the Fisheries Research Board of Canada 33:1964-1971.

Eiane, K., D. L. Aksnes, and J. Giske. 1997. The significance of optical properties in competition among visual and tactile planktivores: a theoretical study. Ecological Modelling 98:123-136.

Ellis, H. I., T. N. Pettit, and G. C. Whittow. 1983. Field metabolic rates and water turnover in two Hawaiian seabirds. American Zoologist 23:980.

Eriksson, M. O. G. 1985. Prey detectability for fish-eating birds in relation to fish density and water transparency. Ornis Scandinavica 16:1-7.

Falk-Petersen, S. 1981. Ecological investigations on the zooplankton community of Balsfjorden, northern Norway: seasonal changes in body weight and the main biochemical composition of Thysanoessa inermis (Kroyer), T. raschii (M. Sars), and Meganyctiphanes norvegica (M. Sars) in relation to environmental factors. Journal of Experimental Marine Biology and Ecology 49:103-120.

Fite, K. V., and S. Rosenfield-Wessels. 1975. A comparative study of deep avian foveas. Brain, Behavior and Evolution 12:97-115.

Fox, R., S. W. Lehmkuhle, and D. H. Westendorf. 1976. Falcon visual acuity. Science 192:263-265.

Frost, K. J., and L. F. Lowry. 1984. Trophic relationships of vertebrate consumers in the Alaskan Beaufort Sea. Pages 381-401 in P. W. Barnes, D. M. Schell, and E. Reimnitz, editors. The Alaskan Beaufort Sea: ecosystems and environments. Academic Press, New York, New York, USA.

Garcia-Soto, C., E. Fernandez, R. D. Pingree, and D. S. Harbour. 1995. Evolution and structure of a shelf coccolithophore bloom in the western English Channel. Journal of Plankton Research 17:2011-2036.

Gerking, S. D. 1994. Feeding ecology of fish. Academic Press, San Diego, California, USA.

Gibson, R. N., and I. A. Ezzi. 1985. Effect of particle concentration on filter- and particulate-feeding in the herring Clupea harengus. Marine Biology 88:109-119.

Gibson, R. N., and I. A. Ezzi. 1990. Relative importance of prey size and concentration in determining the feeding behaviour of the herring Clupea harengus. Marine Biology 107:357-362.

Giske, J., and D. L. Aksnes. 1992. Ontogeny, season and trade-offs: vertical distribution of the mesopelagic fish Maurolicus muelleri. Sarsia 77:253-261.

Gould, P., P. Ostrom, and W. Walker. 2000. Foods, trophic relationships, and migration of Sooty and Short-tailed Shearwaters associated with squid and large-mesh driftnet fisheries in the North Pacific Ocean. Waterbirds 23:165186.

Hall, S. J., C. S. Wardle, and D. N. MacLennan. 1986. Predator evasion in a fish school: test of a model for the fountain effect. Marine Biology 91:143-148.

Hanamura, Y., Y. Endo, and A. Taniguchi. 1984. Underwater observations on the surface swarm of a euphausiid, Euphausia pacifica in Sendai Bay, northeastern Japan. La Mer 22:63-68.

Haney, J. C., K. M. Fristrup, and D. S. Lee. 1992. Geometry of visual recruitment by seabirds to ephemeral foraging flocks. Ornis Scandinavica 23:49-62.

Haney, J. C., and A. E. Stone. 1988. Seabird foraging tactics and water clarity: are plunge divers really in the clear? Marine Ecology Progress Series 49:1-9.

Hayes, B. P., and M. de L. Brooke. 1990. Retinal ganglion cell distribution and behaviour in Procellariiform seabirds. Vision Research 30:1277-1289.

Hester, F. J. 1968. Visual contrast thresholds of the goldfish (Carassius auratus). Vision Research 8:1315-1335.

Hill, H. J., P. N. Trathan, J. P. Croxall, and J. L. Watkins. 1996. A comparison of Antarctic krill Euphausia superba caught by nets and taken by Macaroni Penguins Eudyptes chrysolophus: evidence for selection? Marine Ecology Progress Series 140:1-11.

Hirsch, J. 1982. Falcon visual sensitivity to grating contrast. Nature 300:57-58.

Holanov, S. H., and J. C. Tash. 1978. Particulate and filter feeding in threadfin shad, Dorosoma petenense, at different light intensities. Journal of Fish Biology 13:619-625.

Hunt, G. L., K. O. Coyle, S. Hoffman, M. B. Decker, and E. N. Flint. 1996. Foraging ecology of Short-tailed Shearwaters near the Pribilof Islands, Bering Sea. Marine Ecology Progress Series 141:1-11.

Hunt, G. L., P. J. Gould, D. J. Forsell, and H. Peterson. 1981. Pelagic distribution of marine birds in the eastern Bering Sea. Pages 689-718 in D. W. Hood and J. A. Calder, editors. The eastern Bering Sea shelf: oceanography and resources. Volume 2. Office of Marine Pollution Assessment, National 
Oceanic and Atmospheric Administration. University of Washington Press, Seattle, Washington, USA.

Hunt, G. L., N. M. Harrison, and J. F. Piatt. 1993. Foraging ecology as related to the distribution of planktivorous auklets in the Bering Sea. Pages 18-26 in K. Vermeer, K. T. Briggs, K. H. Morgan, and D. Siegel-Causey, editors. The status, ecology, and conservation of marine birds of the North Pacific. Canadian Wildlife Service Special Publication, Ottawa, Ontario, Canada.

Hunt, G. L., R. W. Russell, K. O. Coyle, and T. Weingartner. 1998. Comparative foraging ecology of planktivorous auklets in relation to ocean physics and prey availability. Marine Ecology Progress Series 167:241-259.

Jackson, S. 1986. Assimilation efficiencies of White-chinned Petrels (Procellaria aequinoctalis) fed different prey. Comparative Biochemistry and Physiology A 85:301-303.

James, A. G., and K. P. Findlay. 1989. Effect of particle size and concentration on feeding behaviour, selectivity and rates of food ingestion by the Cape anchovy Engraulis $\mathrm{ca}$ pensis. Marine Ecology Progress Series 50:275-294.

Jansen, J. K., P. L. Boveng, and J. L. Bengtson. 1998. Foraging modes of Chinstrap Penguins: contrasts between day and night. Marine Ecology Progress Series 165:161-172.

Kettle, D., and W. J. O'Brien. 1978. Vulnerability of arctic zooplankton species to predation by small lake trout ( $\mathrm{Sal}$ velinus namaycush). Journal of the Fisheries Research Board of Canada 35:1495-1500.

Kinder, T. H., and J. D. Schumacher. 1981. Hydrographic structure over the continental shelf of the southeastern Bering Sea. Pages 31-52 in D. W. Hood and J. A. Calder, editors. The eastern Bering Sea shelf: oceanography and resources. Volume 1. Office of Marine Pollution Assessment, National Oceanic and Atmospheric Administration. University of Washington Press, Seattle, Washington, USA.

Kirkwood, R., and G. Robertson. 1997. The energy assimilation efficiency of Emperor Penguins, Aptenodytes forsteri, fed a diet of Antarctic krill, Euphausia superba. Physiological Zoology 70:27-32.

Land, M. F. 1999. Motion and vision: why animals move their eyes. Journal of Comparative Physiology A185:341352.

Link, J. 1996. Capture probabilities of Lake Superior zooplankton by an obligate planktivorous fish-the lake herring. Transactions of the American Fisheries Society 125: $139-142$

Lovvorn, J. R., D. A. Croll, and G. A. Liggins. 1999. Mechanical vs. physiological determinants of swimming speeds in diving Brünnich's Guillemots. Journal of Experimental Biology 202:1741-1752.

Lovvorn, J. R., and M. P. Gillingham. 1996. Food dispersion and foraging energetics: a mechanistic synthesis for field studies of avian benthivores. Ecology 77:435-451.

Lovvorn, J. R., and D. R. Jones. 1994. Biomechanical conflicts between adaptations for diving and aerial flight in estuarine birds. Estuaries 17:62-75.

Lythgoe, J. N. 1979. The ecology of vision. Oxford University Press, Oxford, UK.

Marshall, A. J., and D. L. Serventy. 1956. The breeding cycle of the Short-tailed Shearwater, Puffinus tenuirostris (Temminck), in relation to trans-equatorial migration and its environment. Proceedings of the Zoological Society of London 127:489-510.

Martin, G. R. 1982. An owl's eye: schematic optics and visual performance in Strix aluco L. Journal of Comparative Physiology 145:341-349.

Martin, G. R., and M. de L. Brooke. 1991. The eye of a Procellariiform seabird, the Manx Shearwater, Puffinus puffinus: visual fields and optical structure. Brain, Behavior and Evolution 37:65-78.

Morgan, W. L., and D. A. Ritz. 1982. Comparison of the feeding apparatus in the Muttonbird, Puffinus tenuirostris (Temminck) and the Fairy Prion, Pachyptila turtur (Kuhl) in relation to the capture of the krill, Nyctiphanes australis Sars. Journal of Experimental Marine Biology and Ecology 59:61-75.

Morgan, W. L., and D. A. Ritz. 1983. Sensory cues and mechanisms involved in the capture of euphausiids by the Australian salmon, Arripis trutta (Bloch \& Schneider). Journal of Fish Biology 23:489-493.

Muntz, W. R. A. 1972. Inert absorbing and reflecting pigments. Pages 529-565 in H. J. A. Dartnall, editor. Photochemistry of vision. Handbook of sensory physiology VII/ 1. Springer-Verlag, Berlin, Germany.

Nevitt, G. 1999. Olfactory foraging in Antarctic seabirds: a species-specific attraction to krill odors. Marine Ecology Progress Series 177:235-241.

Nicholls, D. G., P. Stampton, N. I. Klomp, and M. Schultz. 1998. Post-breeding flight to antarctic waters by a Shorttailed Shearwater Puffinus tenuirostris. Emu 98:79-82.

Nicol, S. 1986. Shape, size and density of daytime surface swarms of the euphausiid Meganyctiphanes norvegica in the Bay of Fundy. Journal of Plankton Research 8:29-39.

Nishiyama, T. 1974. Energy requirement of Bristol Bay sockeye salmon in the central Bering Sea and Bristol Bay. Pages 321-343 in D. W. Hood and E. J. Kelley, editors. Oceanography of the Bering Sea with emphasis on renewable resources. Institute of Marine Science, University of Alaska, Fairbanks, Alaska, USA.

Nonacs, P., P. E. Smith, A. Bouskila, and B. Luttbeg. 1994. Modeling the behavior of the northern anchovy, Engraulis mordax, as a schooling predator exploiting patchy prey. Deep-Sea Research 41:147-169.

O'Brien, D. P. 1987. Description of escape responses of krill (Crustacea: Euphausiacea), with particular reference to swarming behavior and the size and proximity of the predator. Journal of Crustacean Biology 7:449-457.

O'Brien, D. P. 1988. Surface schooling behaviour of the coastal krill Nyctiphanes australis (Crustacea: Euphausiacea) off Tasmania, Australia. Marine Ecology Progress Series 42:219-233.

O'Connell, C. P., and J. R. Zweifel. 1972. A laboratory study of particulate and filter feeding of the Pacific mackerel, Scomber japonicus. Fishery Bulletin 70:973-981.

Ogi, H., T. Kubodera, and K. Nakamura. 1980. The pelagic feeding ecology of the Short-tailed Shearwater Puffinus tenuirostris in the subarctic Pacific region. Journal of the Yamashina Institute of Ornithology 12:19-43.

Oka, N., and N. Maruyama. 1986. Mass mortality of Shorttailed Shearwaters along the Japanese coast. Tori 34:97104.

Oka, N., N. Maruyama, and I. Skira. 1987. Chick growth and mortality of Short-tailed Shearwaters in comparison with Sooty Shearwaters, as a possible index of fluctuations of Australian krill abundance. Proceedings of the National Institute of Polar Research Symposium on Polar Biology 1:166-174.

Pepin, P., J. A. Koslow, and S. Pearre. 1988. Laboratory study of foraging by Atlantic mackerel, Scomber scombrus, on natural zooplankton assemblages. Canadian Journal of Fisheries and Aquatic Sciences 45:879-887.

Price, H. J. 1989. Swimming behavior of krill in response to algal patches: a mesocosm study. Limnology and Oceanography 34:649-659.

Prince, P. A. 1980. The food and feeding ecology of Blue Petrel (Halobaena caerulea) and Dove Prion (Pachyptila desolata). Journal of Zoology, London 190:59-76.

Reymond, L., and J. Wolfe. 1981. Behavioural determination of the contrast sensitivity function of the eagle Aquila audax. Vision Research 21:263-271.

Sameoto, D. D. 1983. Euphausiid distribution in acoustic 
scattering layers and its significance to surface swarms. Journal of Plankton Research 5:129-143.

Sanderson, S. L., J. J. Cech, and A. Y. Cheer. 1994. Paddlefish buccal flow velocity during ram suspension feeding and ram ventilation. Journal of Experimental Biology 186:145156.

Schneider, D. C., and V. P. Shuntov. 1993. The trophic organization of the marine bird community in the Bering Sea. Reviews in Fisheries Science 1:311-335.

Serventy, D. L. 1967. Aspects of the population ecology of the Short-tailed Shearwater Puffinus tenuirostris. Proceedings of the International Ornithological Congress 14:165190.

Simard, Y., R. de Ladurantaye, and J.-C. Therriault. 1986. Aggregation of euphausiids along a coastal shelf in an upwelling environment. Marine Ecology Progress Series 32: 203-215.

Sims, D. W. 1999. Threshold foraging behaviour of basking sharks on zooplankton: life on an energetic knife-edge? Proceedings of the Royal Society of London B266:14371443.

Sivak, J. G., H. C. Howland, and P. McGill-Harelstad. 1987. Vision of the Humboldt Penguin (Spheniscus humboldti) in air and water. Proceedings of the Royal Society of London B229:467-472.

Smith, S. L. 1991. Growth, development and distribution of the euphausiids Thysanoessa raschi (M. Sars) and Thysanoessa inermis (Kroyer) in the southeastern Bering Sea. Polar Research 10:461-478.

Snyder, A. W., S. B. Laughlin, and D. G. Stavenga. 1977. Information capacity of eyes. Vision Research 17:11631175.

Spear, L. B., and D. G. Ainley. 1999. Migration routes of Sooty Shearwaters in the Pacific Ocean. Condor 101:205218.

Stockwell, D. A., T. E. Whitledge, S. I. Zeeman, K. O. Coyle, J. M. Napp, R. D. Brodeur, A. I. Pinchuk, and G. L. Hunt. 2001. Anomalous conditions in the south-eastern Bering Sea, 1997: nutrients, phytoplankton, and zooplankton. Fisheries Oceanography 10:99-116.

Stramska, M., and T. D. Dickey. 1998. Short-term variability of the underwater light field in the oligotrophic ocean in response to surface waves and clouds. Deep-Sea Research I 45:1393-1410.

Sugimoto, T., and K. Tadokoro. 1997. Interannual-interdecadal variations in zooplankton biomass, chlorophyll concentration and physical environment in the subarctic Pacific and Bering Sea. Fisheries Oceanography 6:74-93.

Sukhanova, I. N., and M. V. Flint. 1998. Anomalous blooming of coccolithophorids over the eastern Bering Sea shelf. Oceanology 38:502-505.

Swennen, C., and P. Duiven. 1991. Diving speed and foodsize selection in Common Guillemots, Uria aalge. Netherlands Journal of Sea Research 27:191-196.

Thetmeyer, H., and U. Kils. 1995. To see and not be seen: the visibility of predator and prey with respect to feeding behaviour. Marine Ecology Progress Series 126:1-8.
Ulenaers, P., J. van Vessem, and A. A. Dhondt. 1992. Foraging of the Great Crested Grebe in relation to food supply. Journal of Animal Ecology 61:659-667.

Utne, A. C. W. 1997. The effect of turbidity and illumination on the reaction distance and search time of the marine planktivore Gobiusculus flavescens. Journal of Fish Biology 50:926-938.

Vance, T. C., J. D. Schumacher, P. J. Stabeno, C. T. Baier, T. Wyllie-Echeverria, C. T. Tynan, R. D. Brodeur, J. M. Napp, K. O. Coyle, M. B. Decker, G. L. Hunt, D. Stockwell, T. E. Whitledge, M. Jump, and S. Zeeman. 1998. Aquamarine waters recorded for the first time in the eastern Bering Sea. EOS, Transactions, American Geophysical Union 79:121, 126.

Veit, R. R., J. A. McGowan, D. G. Ainley, T. R. Wahl, and P. Pyle. 1997. Apex predator declines ninety percent with changing oceanic climate. Global Climate Change 3:2328.

Wanless, S., S. K. Finney, M. P. Harris, and D. J. McCafferty. 1999. Effect of the diel light cycle on the diving behaviour of two bottom feeding marine birds: the Blue-eyed Shag Phalacrocorax atriceps and the European Shag P. aristotelis. Marine Ecology Progress Series 188:219-224.

Watkins, J. L., and A. W. A. Murray. 1998. Layers of Antarctic krill, Euphausia superba: Are they just long krill swarms? Marine Biology 131:237-247.

Weimerskirch, H., and Y. Cherel. 1998. Feeding ecology of Short-tailed Shearwaters: breeding in Tasmania and foraging in the Antarctic? Marine Ecology Progress Series 167:261-274.

Weimerskirch, H., and P. M. Sagar. 1996. Diving depths of Sooty Shearwaters Puffinus griseus. Ibis 138:786-794.

Werner, E. E., and D. J. Hall. 1974. Optimal foraging and the size selection of prey by the bluegill sunfish (Lepomis macrochirus). Ecology 55:1042-1052.

Willette, T. M., R. T. Cooney, and K. Hyer. 1999. Predator foraging mode shifts affecting mortality of juvenile fishes during the subarctic spring bloom. Canadian Journal of Fisheries and Aquatic Sciences 56:364-376.

Wilson, R. P., K. Puetz, C. A. Bost, B. M. Culik, R. Bannasch, T. Reins, and D. Adelung. 1993. Diel dive depth in penguins in relation to diel vertical migration of prey: whose dinner by candlelight? Marine Ecology Progress Series 94: 101-104.

Wood, C. C., and C. M. Hand. 1985. Food-searching behaviour of the Common Merganser (Mergus merganser). I: Functional responses to prey and predator density. Canadian Journal of Zoology 63:1260-1270.

Wright, D. I., and W. J. O'Brien. 1982. Differential location of Chaoborus larvae and Daphnia by fish: the importance of motion and visible size. American Midland Naturalist 108:68-73.

Wright, D. I., and W. J. O'Brien. 1984. The development and field test of a tactical model of the planktivorous feeding of white crappie (Pomoxis annularis). Ecological Monographs 54:65-98.

Zaitsev, Y. P. 1992. Recent changes in the trophic structure of the Black Sea. Fisheries Oceanography 1:180-189. 